\title{
Computing for Social Good: Supporting Microfinance Institutions in Zambia
}

\begin{abstract}
We investigate whether information and communication technologies (ICTs) can be used to achieve social good as they are implemented in microfinance institutions (MFIs) in Zambia. We find through information gathered from interviews with microfinance institution officials that their organisations are focused primarily on survival in a competitive financial climate. Additionally, our findings reveal that most MFI business within the context of ICTs only promotes social good by default and not by design. This means that social good is not a primary mover or something that MFIs plan to achieve when they integrate ICTs into their business models but that it happens due to the assumed mission of primarily serving the informal sector small and micro businesses and the lowincome clients.
\end{abstract}

Keywords: social good, microfinance, microfinance institutions, information communication technologies, financial inclusion, Zambia

\section{Introduction}

We investigate whether information and communication technologies (ICTs) can be used to achieve social good as they are implemented in microfinance institutions (MFIs) in Zambia. Murdoch (1999) makes a link between government failed assistance to the poor and what he terms 'unusual' financial institutions, which have become known as microfinance institutions. Many argue that government's attempt at assisting the poor failed and that for all intents and purposes government was creating a culture of dependency and disincentives thereby making the plight of the poor even worse (Adams and Von-Pischke, 1992; Balkentol, 2007; Hermes, Lensink \& Meesters, 2011; Hulme and Mosley, 1996; Johnson and Rogaly 1997). However, the mushrooming of 'unusual' financial institutions that have been developed to service low-income households excluded from the formal banking sector has allowed such households to improve their standing in society. This improvement came about because low-income households, individuals, or groups of individuals were able to borrow small sums, set up small-scale businesses with little to no collateral, and thereby build assets. Duvendack et al. (2011) indicate that the concept of microfinance has now evolved not only to provide financial help to the poor but also to include a variety of services such as savings, insurance, and remittances and non-financial services including financial literacy training and skills development programmes. Despite this evolution, the original concept of microfinance still remains:to help those without much financial access and prowess in society.

With the evolution of microfinance and the drive for financial inclusion has come the desire and aspiration by MFIs to use ICTs in their day-to-day business. This is unsurprising because almost all aspects of life have been impacted by the use of ICTs and as a result ICTs are viewed as panaceas to improve the lives of many in society. To illustrate how ICTs are having an impact particularly in developing countries, we can look at Maurer's (2012) article on mobile money. He discusses how mobile phone- 
enabled systems are broadening financial inclusion for the unbanked. He goes on to state "with mobile money, people are potentially setting in motion new media of exchange, methods of payment and stores of wealth and possibly measures of value" (Maurer, 2012, p.601). This has the potential to prop up financial inclusion and economic development for those in the developing world. An example of how mobile phone usage may be having an impact on economic development is given in Blauw and Franses's (2016) article, where the authors highlight results from the evaluation of the impact of mobile telephone use on household income in Uganda. They conclude that there is a strong positive correlation between the proportion of mobile phone users in a household and the economic development of the household. This is the case where mobile phones are used for income generating activities. In addition, they find that the length of mobile phone ownership of the head of the household is also positively correlated with the economic development of the household. These examples demonstrate how ICTs like mobile phones can improve lives. They also show why they can be viewed as panaceas for improvement of life, be it at individual or business level. Another example comes from The World Bank, a leading advocate for financial inclusion for the unbanked or underbanked. It states in its 2012 report that "exclusion from the formal financial system has increasingly been identified as one of the barriers to a world without poverty" (World Bank, 2012, p. 62). Hence, promoting an aspect of social good - alleviating poverty - by creating ways to foster inclusion into the financial system is an important goal. Microfinance institutions form one of these inclusionpromoting systems, one that exists at the intersection of finance and ICTs.

However, the use of ICTs is not without challenges and possible downsides, which raises questions about their potential to achieve social good, particularly when they are woven into the day-to-day functions of MFIs. For instance, issues to do with privacy infringement (Stahl, Jirotka \& Eden, 2013) or surveillance, be it state sponsored or not (Choo \& Sarre, 2015), raise questions about whether social good can be achieved when these issues are taken into consideration. In addition, aspects to do with the reinforcement of gender power relations through use of mobile phones between men and women (Wakunuma, 2012) or the aspect of the digital divide between those with technological know-how and those without as well as those who can afford the technologies and those who cannot (Shirazi et al, 2010) all call for pause for thought as to the extent to which ICTs can automatically achieve social good when adopted by MFIs. Our investigation explores how social good is potentially realised in situations where there is a desire on the part of MFIs to adopt the use of ICTs in their day-to-day businesses. Specifically, we ask the following research question: 'How can MFIs use ICTs for their own survival and consequently for social good'.

\section{Social Good within the Context of ICTs}

The concept of social good has been an essential aspect of many communities and cultures since ancient times (Diggs, 1973). It describes actions of individuals or small groups that promote the well-being of a larger community. Perhaps these actions occur occasionally and without being formally scheduled, such as picking up a plastic bottle and throwing it into the recycling bin. Perhaps these are part of a community involvement program, such as creating a community garden and offering produce to all. At times the concept includes the shared or beneficial tenets or principles for a community as discussed by Jean-Jacques Rousseau in his 1762 treatise, The Social Contract. There are a number of terms that have been used in addition to social good to 
describe the same concept such as common good, general welfare. The concept appears in many philosophical doctrines but varies somewhat from one to the next. The Ancient Greek philosophers included it in their writings. Aristotle, for example, conceived it as attainable at the community level but created by individual actions (Dupre, 1993). It has been shaped by moral philosophers, political theorists, and those who study economics from a public point of view.

Our use of the term falls into the procedural conception of social good, as opposed to the substantive conception. The procedural conception takes a dynamic view by recognizing that social good is achieved through actions that produce outcomes of shared value by a community. The substantive conception focuses on describing the values rather than the process for achieving them. Indeed, in a survey of over 100 papers in the ACM Digital Library with social good as a keyword descriptor or as an element of the title, none described the values. All papers focused on computing systems as a way to achieve values that the authors felt the readers would agree promoted the social good as described by Aristotle. Some scholarly examples that appear in the computing literature relevant to the procedural conception of the social good include Ross (2011), who talks about computer systems that will promote clean air and clean water through monitoring and communication. Ross factors in the use of the power of social networks as central to this element of social good. Chamberlain (2015) and others discuss the importance of web-based systems in order to access healthcare services as an important element that results in social good. Agrawal (2015) on the other hand investigates the role of donation management systems that can allow communities in need of food and clothing to be known to others as a computing system that contributes to social good.

To further expound on the procedural conception of computing for social good, we can also pay attention to how other scholars such as Goldweber (2015) have framed the concept. Goldweber has defined it as "an umbrella term meant to incorporate any educational activity, from small to large, that endeavours to convey and reinforce computing's social relevance and potential for positive societal impact." (p. 15-16). Khan \& Luxton-Reilly (2016) opine that such a definition shows that computing offers an opportunity to solve "profound social problems" (p. 4). In a similar vein, Okunoye \& Sesan (2018) argue for harnessing the potential of data to realise public good. They argue that the use of ICTs has presented multifaceted opportunities for developed countries and it is time for Africa to do the same with the ICT data that is produced on unprecedented scale in order to realise public 'social' good in areas such as healthcare and industry. In these examples, we see that social good within the context of ICTs is about the relevance of computing in empowering its users to achieve positive societal outcomes. Further, we note that ICTs are being presented as enabling social good that brings in marginalised communities that may not have easy access to services like education, health, and those affected by disasters, poverty as well as communication. Such use of ICTs to achieve social good does not seem to be primarily profit-driven but more philanthropic. Notably, such use is not for the survival of the 'philanthropists' but mainly for the benevolence of the marginalised communities.

Thus, from the above, we can understand the term social good within the context of ICTs to mean a benevolent good or service resulting from the use of ICTs that has the potential to benefit a large number of people in a community in the largest possible way without the need for profit. This meaning of social good however excludes social good 
that results from the use of ICTs or potential use of ICTs for purposes of financial sustainability (survival) in addition to their already expected social goal of serving marginalised communities as the case may be for most MFIs. As such, we conceptualise social good within the context of ICTs, particularly when it comes to MFIs adoption of the technologies to mean a service resulting from the use of ICTs that helps its users (MFIs) to be sustainable in their business but also to continue to provide a service to the excluded communities.

\section{[ INSERT FIGURE 1 HERE]}

From the above conceptualisation, it is therefore important to discuss the procedural conception of social good from the point of view of MFIs use of ICTs when they take up the technologies for their own survival and how that might potentially impact their clients. The initial motive may not always be about achieving social good for their clients but survival for themselves first and foremost. The social good is a secondary outcome - but nonetheless a positive outcome. As such, in their desire to adopt ICTs in the day-to-day businesses, MFIs, may not necessarily and explicitly be aiming at addressing a community social problem, but a problem of their own which indirectly results in social good. In this case, MFIs are managing their 'dual responsibilities of social performance and financial sustainability' (Riggins \& Weber, 2016, 17). Thus, as ICTs are brought into the finance system by the MFIs, if their use lifts up the social and economic standing of the unbanked, the MFIs have delivered social good to the communities, perhaps without planning to do so.

In the following sections we further the discussion of social good within the context of ICTs by exploring the connection between microfinance and ICTs. This will be followed by a brief discussion of microfinance in Zambia.

\section{Microfinance and ICTs}

\section{Defining Microfinance}

Microfinance entails the delivery of financial services to poor and low-income households without access to basic financial services for use in their micro-enterprises or productive purposes (CGAP, 2010; Chiu, 2014; Lebovics, Hermes and Hudon, 2016; Tomaselli, Timko \& Kozak, 2013), thereby enabling them to raise their income and living standards. Thus, MFIs of different sizes, types and legal status provide financial services to the poor that are deemed critical for eradicating poverty (Kauffman \& Riggins, 2012; Kimmitt \& Muñoz, 2017). What once started off as microcredit, a simple service offering micro-loans to the world's unbanked populations, and in particular women, has evolved into microfinance, offering broader services, such as deposits, insurance, money transfers and payment products (Bruton, Khavul \& Chavez, 2011; Hermes, Lensick \& Meesters, 2011; Khavul, 2010).

According to Louis, Seret and Baesens (2013, p. 209), "Microfinance institution" is merely an umbrella term. Khavul et al (2013) however notes that MFIs are typically regarded as social enterprises operating in the financial sector that provide financial services including credit, savings, insurance to the poor i.e. individuals previously excluded from financial services. Others note MFI's duality of purpose in that they tend to focus on the explicit pursuit of both social and economic objectives (Battilana \& 
Dorado, 2010, Mair \& Mair, 2009). Nevertheless, microfinance institutions (MFIs) are generally known to specialize in providing small, or "micro," loans (microcredit) to entrepreneurs, primarily in developing countries (Berger \& Nakata, 2013). Over time microfinance has spread around the world and adapted to different local contexts, while MFIs have become increasingly more diverse and complex in nature and in the scope of their offerings (Chiu, 2014; Kimmitt \& Muñoz, 2017). These microfinance institutions tend to be entities of different sizes and legal formats (i.e., non-profit non-governmental organizations (NGOs), for-profit NGOs, self-help groups, ROSCAs, credit unions, cooperatives, non-banking financial institutions, banks, companies, etc.) and have highly diverse lending practices (group lending, village banking, individual lending) (Amerndariz \& Morduch, 2010). Microfinance services may therefore be provided by any type of institution, large or small, formal or informal, and can be regulated or unregulated (De' \& Ratan, 2009; Khavul, Chavez \& Bruton, 2013; Louis, Seret \& Baesens, 2013). However, common to most of these institutions is the aim to provide financial services to poor and low-income people and otherwise marginalized clients (Khavul, et al., 2013; Maitrot, 2018; Mersland \& Strom, 2010), who lack access to formal financial services, to finance their entrepreneurial activities and assist them to advance out of poverty (Armendáriz \& Mordoch, 2010; Thrikawala, Locke \& Reddy, 2013). Not only do these MFIs differ in whom they target, their sizes, legal formats and practice; their missions also tend to vary a lot. Importantly, Hudon and Sandberg (2013) and Ebrahim, Battilana and Mair (2014) note that MFIs are often characterised as hybrid institutions with a twofold agenda: to do good (increase the social outreach of credit) and to do well (achieve financial sustainability). Some institutions, however, are clearly committed to broader development goals, while others are more profit-driven though still committed to the financial inclusion of the poor (Pouchous, 2012).

\title{
ICTs in Microfinance
}

The use of ICTs is evident in extending financial services. In an increasingly competitive and regulated environment, MFIs are under pressure to seek new customers and sustainable models. ICTs uptake therefore may be due to the belief that it is a potential solution to MFI survivability (Kauffman \& Riggins, 2010), and can result in achieving social good by enabling MFIs to extend their outreach, especially to remote areas. Bada (2012, p.1430) points to five ways in which this is possible for MFIs, namely:

\author{
1. Increase MFI staff productivity \\ 2. Reduce transaction costs \\ 3. Remove physical asset barriers to growth \\ 4. Increase range of access point options \\ 5. Facilitate integration \\ 6. Risk analysis and control (Kauffman \& Riggins, 2010)
}

Through aforementioned advantages of ICTs to MFIs, the assumption is that the advantages can then be passed on to clients in the form of reduced costs for services provided. The use of ICTs will also allow MFIs to reach and integrate more clients who may need their services, which includes banking. For example, according to DemirgucKunt, et al., (2014), 34\% of adults in sub-Saharan Africa have a formal bank account, compared to $24 \%$ in 2011 . The region is also reported to be leading the world in mobile 
money accounts at $12 \%$ compared to $2 \%$ worldwide. Accordingly, mobile banking can act in favour of the unbanked poor population. Their inclusion in the formal economy is a real possibility by using mobile services. Transacting with mobile services can also generate a personal record that can act as a basis for assessing creditworthiness and accessing micro-loans or other financial services.

Some previous work on ICTs and microfinance in Africa also suggests a drive towards adoption of ICT by MFIs in order to realise the advantages outlined above. Perampalam \& Suthaharan (2017) have argued that MFIs use of ICTs has the potential to provide increased financial services for the poor at affordable cost. The authors argue that the current high costs experienced by MFIs and subsequently their clients in Northern Sri Lankan is due to extensive use of paperwork and travelling costs. However, if proper policies were to be put in place such as those addressing the right ICT infrastructure, more financial inclusion could result. For instance, in the examination of how ICTs would impact microfinance industry in Africa, Riggins \& Weber (2016) predicted that mobile service providers would enter the microfinance industry as MFIs, providing loans directly to borrowers particularly if MFIs were unable to adapt and to use technology in their business. This trend is now shaping MFIs desire to engage with ICT. In giving their perspective on the use and management of ICTs in microfinance in Bangladesh, Mia and Ramage (2014) suggest that if properly adapted and used, ICTs have the potential to increase operational performance, grow organisations, alleviate poverty as well as decrease interest rates for MFIs. However, Kipesha's (2013) study of ICTs utilization by MFIs in Tanzania shows that while there may be a positive impact on efficiency and financial sustainability when MFIs adopt ICTs, this is short-lived without increasing ICT investments, expanding customer base and increasing ICT usage level. Further, without a proper and supportive ICT policy by the government, the perceived benefits of ICTs to MFIs and their clients cannot be realised. Bada's (2012) study of MFI utilization of ICTs in Uganda also shows challenges related to insufficient bandwidth to enable robust internet connections for businesses to flourish, a lack of an online presence of MFIs to enable microfinance products and services, old and outdated computer hardware and software and ICT illiteracy among staff. However, the United Nations Information Economic Report (2011) highlights Kenya's success with M-Pesa as an example that MFIs can use ICTs by adopting mobile phone-based systems for loan repayments as well as savings account management. For example, some MFIs in Kenya and Tanzania have their own version of M-Pesa, namely the Small and Micro Enterprise Programme (SMEP) and Tujijenge, respectively. In 2009, all of SMEP's 51,000 clients were allowed to make mobile loan repayments and contributions while in Tanzania's case all individual loan repayment of $\$ 1800$ or less were to be made via mobile. These are clear examples of how MFIs have taken advantage of the ubiquitous nature of mobile phones and applied them to their business.

The fact that MFIs have the desire to connect digitally to their clients suggests that there is a strong belief and acceptance in how ICTs can be a strong driver in realising the work they do. For instance, ICTs are seen as a great leveller in that users can bypass difficult ICT infrastructure demands and associated challenges in service delivery through use of mobile phones, thus allowing MFIs to offer financial services to those at the bottom of the pyramid, the poor (Berger \& Nakata, 2013). However, Berger and Nakata argue that although ICTs are a great leveller particularly for the poor, several elements need to be taken into consideration in the provision of financial service innovations that ought to be cost effective. These elements must: 
1. Address customer and agent limits with the technologies, be accepted by users, and be supported by trained staff who monitor technology use and make responsive system adjustments;

2. Exploit and promote supportive governmental regulations and actions, as well as leveraging sound electronic fund transfer (EFT) switches, whether government or bank established;

3. Account for low business capabilities and evolving market competition, along with the underdeveloped financial sector and financial literacy of the population (Berger \& Nakata, 2013, p.1199)

This implies that for any adoption of ICTs in MFIs, the MFIs must ensure that the financial ICT innovation considers the capabilities of their clients and agents in terms of ICT use and know-how. The MFIs must put in place trained staff with knowledge of ICTs and must be able to make the necessary technology adjustments to their systems as and when they are needed. Furthermore, the scholars argue that any such innovation need to consider government regulations and work within those regulations in order to achieve best results. Finally, they argue that the innovations should also consider business capabilities and market competition, which may be financially underdeveloped and serve a population that is financially illiterate. The suggestion is that if these aspects are not taken into consideration, it will be difficult to realise the benefits that ICTs have to offer in MFIs and for the communities they serve.

Adeel, Nett and Wulf (2010) point to third-party involvement and ICT-outsourcing in digitally connecting MFI branches as being on the rise within the MFI community. The involvement of such third-party entities allows MFIs to bypass the development of their own ICT infrastructure. This is understandable in that ICT-outsourcing through thirdparties has the ability to save MFIs resources that they may not readily have including deep ICT knowledge, actual ICT implement, and costs that come with maintaining or upgrading systems. It is clear from the discussion and examples above that ICTs are being seen as important facets in strengthening MFIs' outreach and inevitably, their own financial sustainability. However, what is missing is a thorough analysis of whether and how social good is attainable especially when it comes to considering how ICTs might enable MFIs to better serve their existing clients as well reach out to those hitherto not served. We attempt to give an answer to this by looking at the concept of social good for analysis in our results and discussion section below.

\section{The Microfinance Industry in Zambia}

The financial sector in Zambia is characterised by low financial intermediation, lack of financial services in rural and peri-urban areas, high bank charges and account requirements, poor credit culture, low levels of financial literacy and education, amongst many other challenges (Jang, Benicio \& Chiyaba, 2014). Improving financial access, particularly in rural areas, through expanded financial sector infrastructure has been an on-going theme, making microfinance relevant to dealing with access issues. MFIs in Zambia, as in many other developing countries, have had difficulties reaching remote locations with low population density. According to the 2015 FinScope survey, 
of the $59.3 \%(4.8 \mathrm{~m})$ adults that are financially included ${ }^{1}, 70.3 \%$ are urban while 50.3 $\%$ are rural based. Overall financial exclusion has dropped to $40.7 \%(3.3 \mathrm{~m})$. This is contrasted with the 2009 findings that $62.7 \%(4 \mathrm{~m})$ of adults were financially excluded. One reason for the low level of financial inclusion, according to FinScope 2015, is the high cost of providing financial services, particularly in rural areas and to poorer populations. In responding to these challenges, the Bank of Zambia (BOZ) has strengthened the regulatory environment through the 2006 Act and the new Draft Microfinance Services Bill 2014 (BOZ, 2014a), and allowed for branchless banking as part of its rural finance strategy. Furthermore, BOZ has prepared draft regulations on agency banking thereby providing a low-cost banking solution. Jang et al. (2014) report that authorities have also instituted payment system policies utilising technological developments to extend financial services to the unbanked or underbanked. The introduction of mobile money, for instance, demonstrates the potential of technology in promoting financial inclusion, particularly in rural areas.

The intention of the regulatory framework was to propel the sector to maturity by creating an environment under which MFIs could grow and extend their outreach to the country's rural areas and to low-income clients. Furthermore, it also facilitated easy entry to the sector, with a view to increasing competition that would give consumers a wider choice and eventually bring down the prices of products and services. As of December 2018, there were about 34 MFIs licensed with BOZ, of which nine are Deposit Taking (DT) and 25 are Non-deposit Taking (BOZ, 2018). It is also interesting to note that the majority of licensed MFIs in Zambia are salary-based consumer lenders, concentrated in the main urban areas and account for $92 \%$ of the microfinance sector's total assets (Brouwers et al., 2014)

Increasing access to financial services, especially for women and rural populations is perceived as one way of reducing poverty levels (Brouwers, Chongo, Millinga \& Fraser, 2014). Consequently, the microfinance sector is important to Zambia's goal of addressing mass poverty and, particularly, in enabling micro and small enterprises and access to suitable finance. However, microfinance in Zambia remains unusually undeveloped and access to financial services in Zambia is limited and low, even by regional standards (Jang et al., 2014). The microfinance sector in Zambia has uneven geographical spread of clients (majority located in urban areas) and has seen unsteady growth with most MFIs challenged by their own institutional survival. This limited progress can among other things, be attributed to the poor credit culture amongst clients, potential fraud, low client intake interest rate caps and the high expense of service provision in a country with inadequate transport and communication structure (Chiumya, 2006; Microfinance Transparency, 2011; Siwale \& Ritchie, 2012). Consequently, Zambian MFIs have found it difficult to reach their planned client number and many of the development MFIs can be said to be loss making. Zambia has also lagged behind countries in East Africa in uptake of technology within the microfinance sector and in enacting regulatory framework for microfinance institutions. In a country with a total population of 15.5 million and an adult population estimated at 8.1 million (CSO, 2013), outreach remains low in relation to the potential market.

\footnotetext{
${ }^{1}$ Financially included - Individuals 16 years or over who have/use financial services from formal and informal financial service providers (FinScope, 2015)
} 
Although steady progress has been recorded in the last ten years, challenges to further growth remain.

\section{Methodology}

This project was not initially conceived as a study of ICTs and microfinance, but the fact that ICTs emerged as a key issue shows its importance in the maturing of microfinance in Zambia. One of the researchers entered the field to study the impact of regulations on the governance of MFIs and their ability to deliver on social goals. However, as field work progressed, the role of technology emerged as a key issue in the sustainability of MFIs, client outreach, competition and growth of the sector. Consequently, the researcher adopted an interpretive methodology (Russell, 1996) in an iterative fashion (Hoque, Arends \& Alexander, 2004; Miles \& Huberman, 1994; Scapens, 1990; Yin, 2008), where the researcher, in addition to the initial problem of focus, observes what other issues duly emerge.

For this study it was important to elicit views from practitioners. Consequently, interviews included the Association of Microfinance Institutions in Zambia (AMIZ), a local microfinance expert and 12 officers from six MFIs (see Table 1 below: List of MFIs and position of participants interviewed).

\section{[INSERT TABLE 1 HERE]}

Out of the six MFIs studied, three are amongst the longest and largest established loan enterprise institutions. All six are regulated by the central bank, four operate as deposit taking (DT) and the other two as non-deposit taking (NDT). The 6 MFIs were selected because they mainly target the micro and small and medium size businesses. Majority of their clients are of low-income and in the informal sector. In addition, the MFIs have a great diversity of profiles in terms of legal status, age, size and regulation status.

Initial fieldwork was carried out in July 2015 in Lusaka, Zambia. The choice of country was deliberate as one of the researchers, though resident in the UK, originates from Zambia. The aim was to utilize the researcher's local knowledge and facilitate quicker and relatively easier access to local institutions. We focused on Lusaka because all, except one, registered MFIs with Bank of Zambia are headquartered in Lusaka. However, time and financial constraints did not allow for a bigger interview sample. In total, nineteen ${ }^{2}$ semi-structured interviews were conducted (see Appendix 1: Interview Guide for questions used on ICTs), lasting between forty minutes to an hour and fifty minutes. With informed consent from respondents, all interviews, except one were taperecorded and interviewees were assured anonymity. Thus, the strength of utilising a semi-structured interview style is the ability to provide room for the conversation to flow (Bryman \& Bell, 2011) and to provide the interviewees with the space to develop

\footnotetext{
${ }^{2} 14$ were conducted face to face, while the additional 5, were done through Skype as a followup on the initial round of interviews. This was done to capture additional work on ICTs by MFIs.
} 
the depth of their reflection as well as enabling them to speak in their own "voices" (Llewellyn, 2001). Therefore, while an interview guide was used it was not allowed to constrain the researcher from being open to any new or stand-alone themes that emerged, and hence the theme of the "role of ICTs" (Patton, 1990).

All interviews were in English, semi-structured using broad open-ended questions to elicit participants' interpretations of the regulations, their impacts on respective MFIs and the sector (Goddard, 2004; Maykut \& Morehouse, 1994). Later, data was transcribed from the interview scripts and analysed. Data were analysed through open coding which created a word tree as seen in Figure 2 that highlighted the different ways in which MFIs envisioned the use of technology in their day to day business. For example, if we look at the left-hand sight of the word tree under the label 'using', we see that MFIs envision technology as a way of i) reducing transaction costs and ii) helping the unbanked. Looking at the right-hand side of the word tree, we also see that MFI's were planning to use technology to scale down on bricks and mortar and for survival.

\section{[INSERT FIGURE 2 HERE]}

In looking at Figure 3 below which is the mind map of the bigger project we see that some of the themes that emerge from the coded data include the fact that the desire to use ICTs by the MFIs is more for their own survival first and foremost in order to manage the threat to their sustainability.

\section{[INSERT FIGURE 3 HERE]}

Figure 3 also supports the opening section of the methodology where we stated that although the fieldwork was intended to understand regulations and social goals with respect to MFIs in Zambia, what emerged alongside regulations and social goals were the central role of ICTs in the growth and sustainability of the MFIs. After our initial analysis, follow-up interviews with five of the six MFIs were conducted in October and November 2015, through Skype and email exchanges to make further clarifications on why they thought ICT was a game changer for their long-term sustainability and financial inclusion (especially with reaching rural populations).

\section{Overview of Results}

Consistent with literature, we find that MFIs interviewed acknowledged the importance of ICTs and identified several factors behind the need to leverage technology. Amongst many others, the following were perceived as important: reducing costs, extending outreach, surviving in a harsh competitive environment, minimising fraud and improving customer experience. From a social good perspective and as our conceptualisation of social good demonstrates, there is great potential to exploit benefits of ICTs at the bottom of the pyramid. In addition, our concept also demonstrates that ICTs has the potential to enhance and enable MFIs to scale up their business resulting in 
their long-term sustainability (see our social good conceptualisation Figure 1). For example, the findings suggest that MFIs primary intentions were to use ICTs for overcoming cost issues given an environment their revenues were falling because of a cap on interest rates they could charge. Overcoming infrastructure challenges and other barriers to outreach received less importance at the time. Microfinance interconnectivity in Zambia is possible given the maturity of the mobile network. It is essential for breaking down the isolation of rural areas in terms of access to financial services. Leveraging ICTs can play a major role in ending the financial isolation. As noted in the section on microfinance industry in Zambia, many MFIs have shied away from investing in rural remote branches due to low population density, poor communication and transport infrastructure. In addition, mobile and branchless banking, for example, can penetrate hitherto unserved regions, reach out to more people and reduce the cost of delivery at both the client as well as provider end. As Kamel (2005) has noted, ICT use in microfinance has largely focused on the problem of efficiency enhancement, that is, reducing transactions costs for a large-scale outreach.

\section{Cost Reduction and ICTs}

Discussions with the Association for microfinance institutions and MFIs revealed that cutting costs was motivating the drive for the use of ICTs, which they believed that given the difficult environment resulting from interest rate caps (January 2013November 2015) and falling revenues would enable them to survive as well as increase their client outreach. In an interview with the AMIZ Director, they noted that:

Use of ICTs in microfinance in Zambia is a new development that it is hoped can bring benefits such as lowering cost of delivery of services. As you know microfinance is labour intensive and so use of mobile technology can help minimize numbers e.g. loan officers, thereby lowering the administrative cost. Mobile technology also would overcome barriers such as long distances that characterize most of Zambia's rural areas and at the same lower delivery costs.

This notion of cost reduction and related efficiencies was supported by a senior manager at one of the MFIs, who added that:

Cutting down costs is motivating the drive for the take up of ICTs. We have mobile providers like Airtel, MTN etc., who are willing to partner with MFIs in pushing for increased financial inclusion. Even in urban areas access to services has been a lot easier and cheaper as MFIs seek to operate through agents (agency banking) (Chief Operating Officer, MFI S).

Managers of these MFIs felt there was great potential in ICTs if they can help to bypass the traditional methods of providing microfinance services, especially the provision of credit. This would benefit the unbanked and financially excluded, thereby achieving social good. This is in line with Bada (2012) and Kauffman \& Riggins (2010) views on how social good can be achieved through use of ICTs by MFIs. When asked about how they could use ICTs to reduce costs, interviewed research participants indicated that technology was being perceived as helping in overcoming distance barriers, thereby allowing most MFIs in Zambia that are urban based to extend their rural presence. As such, we argue that a holistic ICT use can deliver on the social good if it succeeds in reducing the cost of delivery at the customer end by saving the consumers both money and time (Ghosh, 2012), especially for those that have to make long commutes to physical bank branches. This also delivers on the MFI in terms of working on a 
branchless model as well as digitising some of the labour-intensive tasks. The bottom line is that ICT use should be efficiency-enhancing not only to the MFIs but to the clients as well. Consequently, De' and Ratan (2009) make a crucial point that the use of ICTs should be seen as a tool for uplifting marginalised groups by offering cheaper and safer means to access financial services. It must change the way clients and providers interact by bringing services nearer to clients in a convenient and relatively cheaper way.

The implication here is that the current business delivery model of brick and mortar and face to face interaction between clients and field or loan officer is expensive and has the potential to restrict access to only those in proximity and ability to pay for services. Zambia has low population density in rural areas making it costly to serve customers outside the few urban centres as MFIs struggle to reach economies of scale. As such, within the Zambian context, MFIs plan to use (and some are using) ICTs for financial inclusion by incorporating the use of mobile phones in cutting down labour intensive aspect of loan disbursement and by partnering with mobile phone providers who have a deeper rural penetration. The perceived huge potential of ICTs in cutting down costs of delivering services has to be contextualised. Achieving financial self-sufficiency has eluded many MFIs in Zambia for years (Chiumya, 2006; Siwale \& Ritchie, 2012), partly due to their high operating costs and lower scalability. Furthermore, the Microfinance Transparency 2011 report notes that Zambia is an expensive place in which to carry out business activities including microfinance activities. Consequently, all MFI managers in this study noted that one of the challenges they face like other MFI managers in many other developing countries is that of reducing client transaction costs (Abdulai \& Tewari, 2017; Kamel, 2005). Failure to do so threatens their financial viability and long-term institutional sustainability. A local microfinance expert was very upfront on this point and was of the view that MFIs in Zambia had to use technology or risk failing altogether. On the other hand, another manager noted that though their MFI had not yet made a huge investment in ICTs, they were still of the view that:

\section{Institutional sustainability hinges on reducing costs and efficiency in providing services, such as money transfers. Technology offers a cheaper way to reach many people and build a huge client base. So, we reckon that if a company spends less, they can in turn use those savings to reach more people. (Branch Manager, MFI T)}

ICTs, in their view were being perceived as an attractive cheaper proposition (Diniz et al 2012; Mathison, 2005), not just for them but for their clients as well. All the key participants thought that the existing harsh environment characterised by interest caps, dwindling revenues and intense competition provided a massive opportunity to expand outreach through new business models based on agent networks and branchless banking using technology. As a way to survive, one practitioner noted:

In a simplistic fashion we have a viability problem. As a result, most MFIs are retrenching or downsizing to survive. However, I think that to survive MFIs have to be innovative and invest in technology in order to reduce transaction costs. Using technology can help to scale down on cost because we are now not thinking of opening branches in form of brick and mortar, but we have introduced agency banking (Acting CEO, MFI T).

Using agents means that MFIs do not have to invest in their own infrastructure, thereby significantly reducing their fixed costs (Lehman \& Ledgerwood, 2013). The experience 
of the two MFIs that had started using agency banking, noted that outreach and access to financial services has improved, enhancing convenience, flexibility and reducing the cost of doing business/undertaking transactions. Nevertheless, even those MFIs whose plans were still on the drawing board, strongly believed that ICTs can help them reduce transactional costs, expand their market, and provide affordable and flexible services to customers-with the right environment. The danger, however, lies in MFIs underestimating the investment in technology that can support back office work and not just use of mobile money. To conclude this section, Zambian MFIs intention to engage with the use of ICTs is primarily driven by the threat to their own survival which is contrary to what literature around social good suggests - which is that of benevolence to the marginalised communities. Although this is a 'side effect', the end game of ICTs usage in this case is that social good is a by-product and not a primary mover for Zambian MFIs.

\section{Outreach and ICTs}

Scaling outreach is important for MFIs -especially for those lending to microentrepreneurs and the poor. Huge client numbers if managed efficiently can support the revenue base of MFIs. In this study, MFI managers observed that ICTs had the potential to promote the dual objectives of microfinance: sustainability and outreach to the financially excluded. As noted by the World Bank Economic Brief (2014) and Brouwers et al., (2014), Zambia's geographical context of low-density population makes reaching rural, low-income individuals especially challenging. In fact, two-thirds of Zambia's population lives in sparsely populated rural areas, making it impossible for most financial service providers to operate profitably. Geographical barriers are a real challenge in the goal of reducing financial exclusion. As Kauffman and Riggins (2012) note, ICTs can help overcome distance barriers and allow MFIs to serve remote rural customers better and in greater numbers. MFIs in Zambia have had limited outreach partly because all of them with an exception of few are concentrated in urban areas, while the rural with huge market potential has gone unserved. Therefore, this can be done via the utilisation of mobile network providers' phone service Booths (known as 'Tunthemba' in Zambian vernacular) that are strewn everywhere in urban and some rural settings. Therefore, the microfinance context is interesting from a rural perspective due to service distance involved, making ICTs relevant to building operational procedures that are lean, safe and effective. This point re-occurred in all conversations across all MFIs interviewed, for the reason that it has potential to provide an intersection between rural outreach and cost reduction.

In terms of rural areas, we are trying to come up with innovation to basically find cheaper ways of servicing the so called unbanked or expensive to manage people. What we are doing is tapping into technology and making use of mobile banking where we don't need to have a physical presence in a rural setting but can rely on say Airtel or MTN facilities to reach out. This is still in discussion with these mobile companies and hopefully that will be the way forward (Head of Banking, MFI P).

Thus, high transaction costs were the most cited major factor inhibiting MFIs to establish physical presence in rural regions. Consequently, most saw the use of mobile phones and agency banking as an attractive proposition (Brouwers et al., 2014) not only for rural areas but also for urban areas where access to services has been made a lot easier through use of agents. Interviewees here indicated that using technology helps 
overcome what Mas (2013, p.304) calls, "the last mile infrastructure" access barrier. In this case the use of ICTs that allow agency banking or mobile banking also serves the poor who may for cost reasons and inconvenience fail to make use of formal financial services. This indication from the Zambian MFIs talked to has a direct connection with how we have conceptualised our understanding of social good in that it specifically shows the indirect way within which social good can result through use of ICTs when survival and sustainability of a business is the primary focus. In addition, findings here support the widely accepted notion that massively expanding access, and therefore financial inclusion, cannot ride on brick-and mortar investments (Lehman \& Ledgerwood, 2013). In particular, deposit taking MFIs are expected by regulation to mimic traditional commercial bank infrastructure before they can take public deposits, a requirement many MFIs said they could not meet and sustain, and hence the fewer physical deposit taking branches even in urban areas.

We are also working on increasing our savings without expending much on brick and mortar. So, we are looking at using mobile banking or services so people can have e-wallets or mobile accounts. We want to see how we can do that without having this sophisticated infrastructure as required by $\mathrm{BOZ}$ of safes and the like-so we might have one or two model branches but leverage more on technology to conduct deposit taking. That is the kind of model that we are working on (Loan Officer, MFI Y).

These brick and mortar branches are an expensive channel to operate, as the fixed and operational costs can be very high. It is therefore reasonable to conclude that, with ICTs at hand, networks of branch banks may not be conducive for reaching remote rural areas or even low-income consumers in urban areas. Therefore, in the Zambian context, the use of ICTs means there is great potential to increase access potential for clients as well as achieve mass outreach. A practical example of achieving this is in partnering with mobile network providers in order to use their investment in network infrastructure and phone service Booths known as Tunthemba for clients to use them for receiving loan amounts as well make loan repayments.

\section{Competition}

It has been noted that, as the microfinance industry matures, ICTs can become an important tool to help MFIs remain afloat in an increasingly competitive environment (Kauffman \& Riggins, 2012; Reeves \& Sabharwal, 2013). The microfinance industry in Zambia is far from being described as mature, yet the environment has become very competitive as commercial banks and mobile service providers compete with MFIs for the same clients (especially in urban and peri-urban settings) in providing financial services. It became evident in our conversations that the emerging intense competition, which most MFIs had not anticipated on the scale it was evolving, was another important factor behind the uptake of ICTs by MFIs. Institutional survival was at stake. According to the interviewed MFIs, the need to leverage technology would give them a competitive edge not only over other MFIs, but also would create space for them to compete with mobile network operators (MNP). It was recognised that MNPs presented a threat because they too had intentions to muscle in on the unbanked clientele. However, despite this threat, the managers felt that partnering with MNPs was better than if the MNPs were taken as direct competitors. As a result, some MFI managers thought that the environment presented opportunities for partnerships with mobile 
network providers (MNPs). The quotes below illustrate this situation.

MFIs need to leverage technology to remain relevant in the future and provide a competitive edge because we are now competing for the same clients with the mobile telephone operators. With the phone, people can make payments for their services, sending money to anywhere in the country at any time. So, the question is why should people continue to come to our brick and mortar offices for financial services? (Loan Officer, MFI W)

Another stated:

MFIs are competing with mobile service providers when it comes to penetrating rural areas, and it might be sensible to ride on their technology. This is because almost every part of Zambia is reachable by these service providers. Mobile technology can assist in disbursing and collecting of money to MFI clients. You may want to know that mobile phones are prevalent in rural areas of Zambia (CEO, MFI Z).

These, new and competitive players have entered this market segment resulting in MFIs ditching their stand-alone approach by collaborating with MNPs and other partners in expanding more cost-effective services. As Perampalam \& Suthaharan (2017) note an increasing competitive environment coupled with industry maturity creates an incentive to use ICTs as a tool for viability and outreach. All MFIs noted that ICT use would provide them flexibility and that it remains a clear competitive advantage in their economic environment of rising business costs, high inflation, and volatile exchange rate and interest rate caps ${ }^{3}$. Riggins \& Weber (2016) make an important point that organisations that are able to implement and make use of modern ICTs will be more likely to survive in a market environment like Zambia and in the future. By partnering with the MNPs, MFIs are able to reach remote rural areas which they would not ordinarily reach. This is a push for financial inclusion which results in MFIs achieving their expected social obligation.

\section{Risk Reduction and Security Improvement}

Before the advent of technologies, MFI personnel often carried large sums of money on their person. With this came an element of risk in the form of fraud and potential physical harm to the person carrying the funds. Given the cash intensive nature of MFI business, use of ICTs can reduce risk of fraud on the part of both the MFI personnel and the client. Personnel carrying large amounts of money to distribute to clients could from time to time find themselves tempted to fraudulently acquire money that is not theirs by for example pretending to have been robbed. Churchill and Coster (2001) and KPMG India (2018) have identified such risk as operational risk where they indicate that fraud is most prevalent where an MFI has a weak information management system and where money changes hands. This they state has an impact on security as handling money particularly in poverty-stricken areas exposes MFIs to theft. One would add that exposure to theft is not only on the MFIs who handle money but on the individuals, they serve as clients. As these individuals become known in an environment where poverty levels are high, they become a potential target for theft and physical harm. The

\footnotetext{
${ }^{3}$ Interest rate caps have since been removed and all MFIs are now back to charging own determined interest rates on lending.
} 
introduction of ICTs within this sector has the potential to change this as noted by the s AMIZ Director

Clients can travel without carrying large amounts of cash with them, thereby solving a basic need tied to security, expressed by people in these communities. In addition, it also helps cut down on fraud by loan officers, as they now won't be directly collecting cash from clients.

The fact that money can be electronically transferred means that it removes the need for MFI personnel to carry large sums of money or for clients who travelled long distances to access their money would now access that electronically without the danger that comes with carrying large amounts.

The findings in this section offer an insight into our conceptualisation of social good in that ICTs has the potential to offer and extend security to clients' funds as well as minimise MFIs risk of fraud or actual physical harm to the employees as they attempt to disburse funds to underserved clients in far flung areas.

\section{Discussion and Conclusion}

As outlined in the methodology section, the initial premise of this paper was to look at the impact of regulations on MFIs and on the resulting social good. However, during the fieldwork in Zambia, it soon became evident that there was importance placed on ICTs and the potential impact these technologies, particularly mobile phone technologies, would have on the survival of MFIs. The fieldwork revealed that MFIs had the intention to incorporate the use of ICTs in their day-to-day running of their institutions. The MFIs believed it was a choice between survival or perishing if they ignored the power of these technologies. A significant factor in this belief is the intense competition amongst MFIs as well as the government's intervention and directives to ensure that MFI clients were getting good value for money for their custom. This factor played a hand in MFIs thinking more about their survival first and foremost and then about their expected obligation to deliver on their social mission of for example reaching out to the unbanked in rural populations. Therefore, providing social good through ICTs for MFIs in Zambia would come by default and not by design. As such, we argue that although social good will often result from the work undertaken by MFIs, it is merely a by-product of the MFIs main aim, that of making a profit from the services they offer. This is an important contribution to the discourse of MFIs and ICTs. Therefore, our contribution has seen us develop a conceptual framework of how social good can be seen within the context of ICTs, particularly with respect to MFIs. It may be that this concept will need to be improved further, but we think that this is a good starting point in understanding this particular discourse.

Results presented in this paper reveal that use of ICTs had the potential to reduce cost for MFIs and their clients. In addition, the results show that MFIs in Zambia expect there to be the opportunity for them to connect with clients in hard to reach areas which has direct implications on them achieving social good for those communities. Further, the results show that the potential use of ICTs boost much needed competition as well as mitigates on risk factors. Conversely, our investigation shows that microfinance institutions have the potential to contribute to the social good by bringing financial resources to rural communities. The information we gathered through interviews with 
MFI officials indicates that they believe the use of ICTs will provide the tools for MFIs to be successful in rural areas and thus will achieve social good as a secondary consequence.

Further explorations of the relationships among MFIs, their use of ICTs, and the social good that accrues to client communities can address several aspects of this situation. ICT use in microfinance is in its early stages in Zambia, which means that the actual client benefits associated with it and the extent to which the uptake of ICTs will be able to contribute to financial inclusion in a transformative way becomes a critical investigation with policy implications. The Zambian Government Central Bank's introduction of interest caps was a clear government policy intervention that has had implications on MFI business survival prospects in terms of ICT use and resulting potential social good. As a result of this, MFIs have had to rethink on how to deliver services in an innovative way. This has involved plans to appropriate and use ICTs in order to survive and remain relevant in the finance arena of the country. This is aptly captured in the following quote by an MFI consultant:

Microfinance must use technology or MFIs will not survive. So, microfinance will not be a significant player in delivering social goals unless we can revisit the model and innovate (Local microfinance expert).

Here, the potential power that technology has on business is aptly displayed. The suggestion is that MFIs have no choice but to adapt to new ways of doing business otherwise they risk being irrelevant. The suggestion is that delivery of social goals goes hand in hand with innovating the business through up take and weaving ICTs in microfinance. As is further indicated by the following quote:

We [MFIs] are having to learn new ways in which financial inclusion can be achieved by using ICTs (Chief Operating Officer, MFI W)

Such inclusion becomes easier when the people who need to be financially included also have the technologies at hand to be included. What then becomes evident is the fact that it is not only MFIs but their clients who become digitally included; which then results in MFIs not only potentially surviving but their clients having an improved customer experience resulting in social good for them. However, for this to become a reality, for example in MFIs reaching the unbanked much more effectively through mobile banking, the MFI business model must be transformational not only for themselves but their clients. As Comninos et al (2008) have suggested, "to become transformational, mobile banking must progress towards bringing more informal businesses and the poor into the formal economy so that they are better able to access micro-loans and other financial services" (p. 1). In conclusion, our findings have shown that context matters in terms of how social good is realised though ICTs as the case has been for Zambian MFIs whose intention is to engage with ICTs for survival first and foremost. This is because ICTs offer MFIs a chance at survival in a competitive climate and incidentally achieve social good for their communities, in this case their clients. The social good is a secondary outcome - but nonetheless a positive outcome. As such, in their desire to adopt ICTs in the day-to-day businesses, MFIs, may not necessarily and explicitly be addressing a community social problem, but a problem of their own which indirectly results in social good. For future research, we suggest that further work be carried out to investigate how ICTs delivers social good from a client perspective. 


\section{References}

Abdulai, A \& Tewari D.D (2017). Trade-off between outreach and sustainability of microfinance institutions: evidence from sub-Saharan Africa. Enterprise Development and Microfinance Vol. 28 (3).

Adams, D. W. and Von Pischke J. D. (1992). "Microenterprise Credit Programs: Dejavu". World Development 20(10): pp.1463-1470

Armendáriz, B. \& Morduch, J. (2010). The Economics of Microfinance, 2nd ed. MIT Press, Cambridge, MA.

Agrawal, R. (2015). Collaborative systems with applications for social good. In Companion to the Proceedings of the 11th International Symposium on Open Collaboration, doi.org/10.1145/2789853.2789858. Retrieved from http://www.opensym.org/os2015/proceedings-files/c100-agrawal.pdf

Agri-ProFocus Zambia (APF). (2014). A Market Study on Microfinance Services in Zambia. APF, Lusaka, Zambia. Retrieved from http://agriprofocus.com/upload/FINAL_REPORT_MF_Study_CMED1425011540.pdf

Alexandre, C., Mas, I \& Radcliffe, D. (2011). Regulating New Banking Models to Bring Financial Services to All. Challenge, 54 (3), 116-134, May/June

Balkenhol, B (2007) Microfinance and public policy. Outreach, performance and efficiency Palgrave Edition, New York (2007)

Bada, J. K. (2012). ICT for business services: The case of Ugandan Microfinance Institutions. IJRRAS, 11 (1), 140-152 Retrieved from http://www.arpapress.com/volumes/vol11issue1/ijrras_11_1_16.pdf

Banisar, D. (2010). Linking ICTs, the right to privacy, freedom of expression and access to information. East African Journal of Peace \& Human Rights, 16 (1)

Bank of Zambia (2006). Banking and Financial Services (Microfinance) Regulation (FSR, 2006) Retrieved from http://www.boz.zm/Instruments/BozGazette.pdf

Bank of Zambia (2014a). Banking and Financial Services (Microfinance) Draft Regulations (Draft FSR 2014), Retrieved from http://www.boz.zm/(S(11qygm5511s4tyrs3bdfi355))/\%5Cpublishing\%5CSpeeches\%5C Draft_Microfinance_Services_Bill_2014.pdf

Bank of Zambia (2018) List of Non-Bank Financial Institutions. http://www.boz.zm/ListofNBFIsat31December2018.pdf

Bank of Zambia, (2014b). The Launch of the Fourth Zambia Economic Brief. Key Note Remarks by the Governor of the Bank of Zambia. Retrieved from

http://www.boz.zm/publishing/Speeches/Governor\%20Notes\%20Launch\%20of\%20fourth\%20 Zambia\%20Economic\%20Brief.pdf

Berger, E. \& Nakata, C.I. (2013). Implementing Technologies for Financial Service Innovations in Base of the Pyramid Markets, Journal of Product Innovation Management, 30 (6), 1199-1211, DOI: 10.1111/jpim.12054 
Blauw, S. \& Franses, P.H. (2016). Off the Hook: Measuring the Impact of Mobile Telephone Use on Economic Development of Households in Uganda using Copulas. The Journal of Development Studies, 52 (3), 315-330, doi: 10.1080/00220388.2015.1056783

Brouwers, D., Chongo, B., Millinga, A. \& Fraser, F. (2014). Microfinance regulatory and policy assessment in SADC- case study of Namibia, Tanzania and Zambia. FinMark Trust and GIZ. Retrieved from http://www.finmark.org.za/wpcontent/uploads/2016/01/Rep_SAMP_MF_Reg_Policy_SADC2.pdf.

Bruton, G.D., Khavul, S. \& Chavez, H., (2011). Microfinance in emerging markets: building a new line of inquiry from the ground up. Journal of International Business Studies 42, 718-739.

Bryman, A. \& Bell, E. (2011). Business Research Methods, 3rd Ed, Oxford University Press, Oxford

CGAP (2010). MIX microfinance world: Sub-Saharan Africa microfinance analysis and benchmarking report 2010', Retrieved from http://www.cgap.org/gm/document1.9.51317/CGAP_MIX_SSA_Benchmarking_Report_2010.pdf

Chamberlain, A., Schraefel, M. C., Poole, E., Munson, S., Danis, C., \& Churchill, E. (2015). Moving beyond e-health and the quantified self: The role of CSCW in collaboration, community and practice for technologically-supported proactive health and wellbeing. In Proceedings of the ACM Conference on Computer Supported Cooperative Work, CSCW. (Vol. 2015-January, pp. 273-276). Association for Computing Machinery. DOI: $\underline{10.1145 / 2685553.2685555}$

Chiu, T.K. (2014). Putting Responsible Finance to Work for Citi Microfinance, Journal of Business Ethics, 119 (2), 219-234. DOI 10.1007/s10551-013-1626-1

Chiumya, C. (2006). The regulation of microfinance institutions: a Zambian case study (Unpublished doctoral thesis), University of Manchester, Manchester.

Churchill, C and Coster, D. (2001) Microfinance Risk Management Handbook. CARE. Retrieved from http://edu.care.org/Documents/Risk\%20Management\%20Handbook.pdf.

Choo, K. K. R. \& Sarre, R. (2015). Balancing Privacy with Legitimate Surveillance and Lawful Data Access. IEEE Cloud Computing, 2(4), 8-13. doi: 10.1109/MCC.2015.84

Comninos, A., Esselaar, S., Ndiwalana, A., \& Christoph Stork (2008) M-banking the Unbanked, Towards Evidence-based ICT Policy and Regulation, Volume 1, Policy Paper 4. Research ICT Africa

Country Survey: ZAMBIA (2011). Microfinance Transparency, June 2011. Mf transparency.org. Promoting Transparent Pricing in the Microfinance Industry

Cruz, P., Lineu Barretto Filgueiras Neto, Pablo Muñoz - Gallego, Tommi Laukkanen, (2010). Mobile banking rollout in emerging markets: evidence from Brazil. International Journal of Bank Marketing, 28 (5), 342 - 371 doi.org/10.1108/02652321011064881 
Davis, Fred (1985), A Technology Acceptance Model for Empirically Testing New End-User Information Systems. PhD Thesis, MIT Sloan School of Management.

Demirguc-Kunt, A., Klapper, L., Singer, D \& Van Oudheusden, P. (2014).The Global Findex Database 2014 Measuring Financial Inclusion around the World, World Bank Policy Research Working Paper 7255, World Bank. Retrieved from http://wwwwds.worldbank.org/external/default/WDSContentServer/WDSP/IB/2015/10/19/090224 b08315413c/2_0/Rendered/PDF/The0Global0Fin0ion0around0the0world.pdf\#page $=3$

Diggs, B. J. (1973). The Common Good as Reason for Political Action. Ethics, 83 (4), $283-$ 284.

Diniz, E., Birochi, R \& Pozzenbon, M (2012) Triggers and barriers to financial inclusion: The use of ICT-based branchless banking in an Amazon county. Electronic Commerce Research and Applications 11 (2012) 484-494

Dupré, L. (1993). The Common Good and the Open Society. The Review of Politics, 55, 687712. doi:10.1017/S0034670500018052.

Duvendack, M., Palmer-Jones, R., Copestake, J.G., Hooper, L., Loke, Y. \& Rao N. (2011). What is the evidence of the impact of microfinance on the well-being of poor people? London: EPPI-Centre, Social Science Research Unit, Institute of Education, University of London. ISBN: 978-1-907345-19-7 Retrieved from https://www.givedirectly.org/pdf/DFID_microfinance_evidence_review.pdf

Ebrahim, A., Battilana, J. \& Mair, J. (2014). The governance of social enterprises: Mission drift and accountability challenges in hybrid organizations. Research in organizational behaviour, 34, 81-100

Feigenberg, B. Field, E. M \& Pande, R. (2010). Building Social Capital Through Microfinance, NBER Working Paper No. 16018 May 2010 JEL No. C81, C93, O12, O16, http://www.nber.org/papers/w16018.pdf

FinScope Zambia 2015. Retrieved from http://www.boz.zm/Publishing/77/77_FSD_Zambia_Final\%20II.pdf

Frankiewicz, C. (2003). Information technology as a strategic tool for microfinance in Africa: A seminar report. Paper presented at AfriCap: The First African Investment Fund for Commercial Microfinance, Nairobi, Kenya, April 26-27. Retrieved from http://www.microfinancegateway.org/sites/default/files/mfg-en-paper-informationtechnology-as-a-strategic-tool-for-microfinance-in-africa-apr-2003.pdf. Accessed: $12 / 3 / 16$

Ghosh, I. (2012). The Mobile Phone as a Link to Formal Financial Services: Findings from Uganda. ICTD '12 Proceedings of the Fifth International Conference on Information and Communication Technologies and Development, March 12-15, 140-148, Atlanta, USA. doi.10.1145/2160673.2160693

Gino, F. \& Pisano, G. P. (2008). Toward a Theory of Behavioral Operations Manufacturing \& Service Operations Management 10 (4), 676-691. doi: $10.1287 / \mathrm{msom} .1070 .0205$. 
Goddard, A. (2004). Budgetary practices and accountability habitus: A grounded theory. Accounting, Auditing and Accountability Journal, 17 (4), 543-577.

Goldweber, M. (2015). Computer science education for social good. ACM SIGCAS Computers and Society 45 (2):29-30. doi.org/10.1145/2809957.2809963

Goldweber, M., Barr, J \& Patitsas, E. (2013) Computer Science Education for Social Good. In Proceeding of the 44th ACM Technical Symposium on Computer Science Education, SIGCSE '13, Pp. 15-16. New York, NY, USA, 2013. ACM.

Guganeshan, M. \& Suthaharan, P. (2017) Understanding ICT's Role in Microfinance to Improve Financial Inclusion in Northern Sri Lanka (September 27, 2017). Available at SSRN: https://ssrn.com/abstract=3043721 or http://dx.doi.org/10.2139/ssrn.3043721

Hermes, N., Lensink, R. \& Meesters, A. (2011). Outreach and efficiency of microfinance institutions. World Development, 39 (6), 938-948

Hoque, Z., Arends, S. \& Alexander, R. (2004). Policing the police: a case study of the rise of new public management within an Australian police service. Accounting, Auditing \& Accountability Journal, 17 (1) 59-84.

Hudon, M. \& Sandberg, J. (2013). The ethical crisis in microfinance: issues, findings, and implications, Business Ethics Quarterly, vol. 23 (4) pp. 561-589

Hulme, D. and P. Mosley (1996). Finance against Poverty. Vols. 1 and 2. London, Routledge.

Jang, B.K., Benicio, D. \& Chiyaba, G. (2014). Enhancing Financial Inclusion in Zambia. Washington: International Monetary Fund

Johnson, S. and Rogaly, B. (1997). Microfinance and Poverty Reduction, Oxford: OXFAM.

Kamel, S. (2005). The use of information technology to transform the banking sector in developing nations: Editorial introduction. Information Technology for Development, 11(4), 305-312.

Kauffman, R. J. \& Riggins, F.J. (2012). Information and communication technology and the sustainability of microfinance. Electronic Commerce Research and Applications 11, $450-468$.

Khan, N. \& Luxton-Reilly, A. (2016) Is computing for social good the solution to closing the gender gap in computer science? ACSW '16 Multiconference, February 02 - 05, 2016, Canberra, Australia. DOI: http://dx.doi.org/10.1145/2843043.2843069

Khavul, S. (2010). Microfinance: creating opportunities for the poor? Academy of Management Perspectives 24 (3), 58-72

Khavul, S., Chavez, H. \& Bruton, G. (2013). When institutional change outruns the change agent: The contested terrain of entrepreneurial microfinance for those in poverty. Journal of Business Venturing, 28, 20-50. 
Kimmitt, J., \& Munoz, P., (2017). Entrepreneurship and Financial Inclusion through the Lens of Instrumental Freedoms. International Small Business Journal, 35 (7), 803-823.

KPMG (2018) Microfinance -The crucial link in inclusiveness in Eastern India.

https://assets.kpmg/content/dam/kpmg/in/pdf/2018/01/Microfinance.pdf. Accessed 10/1/19

Kipesha, E. F. (2013). Impact of ICT Utilization on Efficiency and Financial Sustainability of Microfinance Institutions in Tanzania. Interdisciplinary Studies on Information Technology and Business (ISITB), 1 (1), 67-82

Kuriyan, R., Kitner, K., \& Watkins, J. (2010). ICTs, development and trust: An overview. Information Technology \& People, 23(3), 216-221. doi.org/10.1108/09593841011069130

Lebovics, M., Hermes N. and Hudon M., 2016, 'Are financial and social efficiency mutually exclusive? A case study of Vietnamese microfinance institutions', Annals of Public and Cooperative Economics, 87, 55-77.

Lederer, A. L., Maupin, D. J., Sena, M. P., \& Zhuang, Y. (2000) The technology acceptance model the World Wide Web. Decision Support Systems, 29, (3), 269-283.

Ledgerwood, J. (2013) Microfinance Handbook: An Institutional and Financial Perspective. World Bank, Washington, DC, 2000.

Lehman, J. \& Ledgerwood, J. (2013). Payment Services and Delivery Channels. In J. Ledgerwood (Eds.), The new microfinance handbook (pp. 271-298) Washington, DC: The World Bank

Lin, J., Lu, Y., Wang, B \& Wei, K.K. (2011). The role of inter-channel trust transfer in establishing mobile commerce trust. Electronic Commerce Research and Applications, 10 (6), 615-625.

Llewellyn, S. (2001). Two-way windows': clinicians as medical managers. Organization Studies 12(3), 593-623.

Louis P., Seret, A. \& Baesens, B. (2013). Financial Efficiency and Social Impact of Microfinance Institutions Using Self-Organizing Maps. World Development, 46, 197210

Lusaka Times (2016) https://www.lusakatimes.com/2016/01/27/zambias-mobile-phone-usersjump-from-2-6-million-to-10-9-million-in-8-years/, Accessed on 20/04/2016

MacKenzie, D. \& Wajcman, J. The Social Shaping of Technology. Bell and Bain, Ltd, London, 1999.

Mas, I. (2013). Beyond Products: Building Integrated Customer Experiences on Mobile Phones. In J. Ledgerwood (Eds.), The new microfinance handbook (pp.299-318) Washington, DC: The World Bank

Mathison, S. (2005). Increasing the outreach and sustainability of microfinance through ICT innovation. In S. Mathison (Ed), Electronic banking with the poor: Increasing the 
outreach and sustainability of microfinance through ICT innovation (pp. 1-7) Brisbane, Australia: The Foundation for Development Cooperation.

Maurer, B. (2012) Mobile Money: Communication, Consumption and Change in the Payments Space, The Journal of Development Studies, 48 (5), 589-604, DOI:

10.1080/00220388.2011.621944

Maykut, R \& Morehouse, R. (1994). Beginning Qualitative Research: A Philosophical and Practical Guide, The Falmer Press, London.

Mersland, R. (2009). The cost of ownership in microfinance organizations', World Development, 37(2), 469-78. doi:10.1016/j.worlddev.2008.03.006

Mersland, R. \& Strom, R.O. (2010). Microfinance mission drift? World Development, 38(1), 28-36 doi:10.1016/j.worlddev.2009.05.006

Mia, M. B. \& Ramage, M. (2104) Use and Management of Conventional ICT and Mobile Technology Microfinance: A Bangladesh Perspective IN ICT Management in NonProfit Organizations DOI: 10.4018/978-1-4666-5974-2.ch009

Microfinance Institutions in Tanzania. Interdisciplinary Studies on Information Technology and Business (ISITB), 1 (1), January -March 2013 (67 - 82)

Miles, M.B. \& Huberman, A.M. (1994). Qualitative Data Analysis: A Sourcebook of New Methods, Sage, Beverly Hills, CA.

Murdoch, J. (1999). The Microfinance Promise. Journal of Economic Literature, 37 (4) 15691614.

Parikh, T., Javid, p., Sasikumar, K., Ghosh, K \& Toyama, K. (2006). Mobile Phones and Paper Documents: Evaluating a New Approach for Capturing Microfinance Data in Rural India, Proc. CHI 2006, 551-560, April 22-27, 2006, Montreal, Quebec. doi>10.1145/1124772.1124857

Patton, M. Q. (1990). Qualitative evaluation and research methods. Beverly Hills, California: Sage

Pouchous, A. (2012). The Regulation and Supervision of Microfinance: Main issues and progress, TKN Report. International Institute for sustainable development (IISD) http://www.iisd.org/pdf/2012/regulation_supervision_microfinance.pdf

Ramakrishnan, R. \& Webb, G.I. (2014). Does social good justify risking personal privacy? In Proceedings of the 20th ACM SIGKDD international conference on Knowledge discovery and data mining (KDD '14), 1965-1965.doi.org/10.1145/2623330.2630814

Rahul, D. \& Ratan, A. L. (2009). Whose gain is it anyway? Structurational perspectives on deploying ICTs for development in India's microfinance sector. Information Technology for Development, 15 (4) 259-282, doi.10.1002/itdj.20129.

Ratan, A.L., Chakraborty, S., Chitnis, P.V., Toyama, K., Ooi, K.S., Phiong, M \& Koenig, M. (2010). Managing Microfinance with Paper, Pen and Digital Slate. ITD Information Technologies and International Development, 8 (2), 67-83. 
Reeves, M. \& Sabharwal, N. (2013). Microfinance and mobile banking for the bottom of the pyramid, Journal of Enterprising Communities: People and Places in the Global Economy, 7 (2) 155-166

Riggins, F. and Weber, D. (2016). Exploring the Impact of Information and Communication Technology (ICT) on Intermediation Market Structure in the Microfinance Industry. The African Journal of Information Systems: Vol. 8: 3, 1.

Ross, J. (2011). Pervasive negabehavior games for environmental sustainability. In: Proceedings of ACM CHI 2011 Conference on Human Factors in Computing System, 2011, pp. 1085-1088. dx.doi.org/10.1145/1979742.1979694

Russell, J. (1996). An approach to organisational ethnographic research: strategy, methods and processes. Southampton, UK, University of Southampton, 36pp. (Discussion Papers in Accounting and Management Science, 96-122). http://eprints.soton.ac.uk/36155/

Scapens, R.W. (1990). Researching management accounting practice: the role of case study. The British Accounting Review, 22 (3), 259-81.

Shirazi, F., Ngwenyama, O. \& Morawczynski, O. (2010). ICT expansion and the digital divide in democratic freedoms: An analysis of the impact of ICT expansion, education and ICT filtering on democracy. Telematics and Informatics, 27, 21-31

Siwale, J. \& Ritchie, J. (2013). Accounting for microfinance failure: insights from Zambia. International Journal of Critical Accounting, 5 (6), 641-662.

Siwale, J. N. \& Ritchie, J. (2012). Disclosing the loan officer's role in microfinance development. International Small Business Journal, 30, 432-450. doi:10.1177/0266242610373687

Stahl, B.C., Eden, G. \& Jirotka, M. (2013). Responsible Research and Innovation in Information and Communication Technology: Identifying and Engaging with the Ethical Implications of ICTs. In R. Owen, J. Bessant and M. Heintz (Eds.), Responsible Innovation: Managing the Responsible Emergence of Science and Innovation in Society, John Wiley \& Sons, Ltd, Chichester, UK. doi: 10.1002/9781118551424.

Stork, C. (2012). Mobile Money - What's Next? Research ICT solutions. Proc. ICTD 2012. Retrieved from: http://researchictsolutions.com/wp-content/uploads/2015/05/MobileMoney-What\%E2\%80\%99s-next-ICTD-2012.pdf

Tang, DongPing, \& Chen, LianJin (2011). A review of the evolution of research on information Technology Acceptance Model. Proc. Intl. Conf. on Business Management and Electronic Information, 588-591. doi: 10.1109/ICBMEI.2011.5917980

Thrikawala, S., Locke, S. \& Reddy, K (2013). Social Performance of Microfinance Institutions (MFIs): Does Existing Practice Imply a Social Objective? American Journal of Business and Management, 2 (2), 173-180 
Tomaselli, M.F., Timko, J. \& Kozak, R. (2013). Assessing Small and Medium Forest Enterprises' Access to Microfinance: Case Studies from The Gambia. Journal of Development Studies, 49, 334-347. doi:10.1080/00220388.2012.740018.

Trist, E. (1990). Introduction to volume II: The socio-technical perspective. In E. Trist \& H. Murray (Eds.), The social engagement of social science: A Tavistock anthology, (pp. 36-60). Philadelphia: University of Pennsylvania Press.

United Nations. (2011). Information Economy Report 2011: ICTs as an Enabler for Private Sector Development. United Nations Conference on Trade and Development (UNCTAD)

Venkatesh, V, et al (2003). User acceptance of information technology: Toward a unified view. MIS Quarterly (2003): 425-478.

Wakunuma, K. (2012). Implicating mobile phones in violence against women: What's gender got to do with it? GenderIT.org http://www.genderit.org/resources/implicating-mobilephones-violence-against-women-what-s-gender-got-do-it

Weber, D.M. \& Kauffman, R.J. (2011). What drives global ICT adoption? Analysis and research directions. Electronic Commerce Research and Applications 10, 683-701.

World Bank (2012). 2012 Information and Communications for Development : Maximizing Mobile. Washington, DC: World Bank. (C) World Bank. https://openknowledge.worldbank.org/handle/10986/11958 License: CC BY 3.0 IGO. http://hdl.handle.net/10986/11958

World Bank (2014). Zambia economic brief: financial services - reaching every Zambian. Zambia economic brief; issue 4. Washington, DC: World Bank Group. http://documents.worldbank.org/curated/en/2014/12/23036169/zambiaeconomic-brief

Yin, R. K. (2008). Case study research: Design and methods (4th Ed.) Thousand Oaks, CA: Sage Publications 


\section{Appendices}

\section{Appendix 1: Interview Guide}

\section{$\underline{\text { Interview guide questions } 2015}$}

1. As director of the Association of microfinance institutions in Zambia, would you share your views on why use of technology has become critical and how it is being used?

$\underline{\text { Interview guide questions for managers and CEO }}$

1. What is the role of ICT from an institutional perspective?

2. How is use of technology impacting on your delivery of financial services?

3. What are the motivating factors behind the push for increased use of ICTs in your organisation?

4. What are some of the challenges you are facing as an MFI in making more use of ICTs?

5. Based on your experience working in this organization, which people do you think use of ICT is going to benefit the most?

6. How are ICTs changing the landscape of MFIs in Zambia?

\section{Broad questions for Loan officers}

1. In your view, what is driving all this push for ICT adoption?

2. From a loan officer's perspective, how is your MFI planning on utilising technology to reach out to the financially unbanked and underbanked?

3. What in your view are potential benefits to your clients and your organisation? 